\title{
Influence of Relative Age Effect on competitive shooters of clubs SSK Dukla Hradec Králové and SSKP Kometa Brno
}

\author{
Jakub Tomeček, Michal Bozděch
}

Faculty of Sport Studies, Masaryk University Brno

\begin{abstract}
This article deals with the issue of Relative Age Effect (RAE), which enables the exploration of differences and links between the expected and observed distribution of birth date of athletes based on their date of birth. It is expected that into the elite choice are chosen athletes, who were born in the beginning of the year. Therefore, athletes born in last months of year are disadvantaged. In this article, RAE was tested by the means of chi-squared test in Goodness-of-fit test and Kolmogorov-Smirnov test. Afterwards, Cramer's $V$ was used for more accurate estimation of a potency of the association between expected and observed distribution. By the usage of methods previously mentioned it was found out that in selected sport clubs, the results of RAE are not statistically confirmed, however, different connections, which cannot be left unnoticed, were observed. In the conclusion, there is stated that even though it is not obvious on the fleeting glance, the junior category in more influenced by RAE than the senior category. This fact is as such affected also by the nature of shotgun shooting, it emphasizes overall physical condition and physique rather than separate physical and age details of a shooter.
\end{abstract}

Keywords: birthdate, athlete talent, juniors, seniors, skeet, shotgun, trap, national team, RAE, shooting, Czech,

\section{INTRODUCTION}

The issue known as Relative Age Effect (RAE) was first studied by Green and Simmons (1962), who conducted a research of pupils at the elementary school level. They found out that pupils who were born in the first half of the year got higher grades than the rest of the class. The issue was introduced into sport field by authors Barnsley, Thompson, and Barnsley (1985), who confirmed the overrepresentation of players who were born in the first quartal $\left(\mathrm{Q}_{1}\right)$ over players born in the last quartal $\left(\mathrm{Q}_{4}\right)$. The research was conducted on the ice-hockey players of different age and categories (NHL, WHI, OHL).

The sport which uses the RAE with the highest frequency is football, where for example the authors Deprez, Vaeyens, Coutts, Lenoir, and Philippaerts (2012) found out, that the influence is statistically important in the age categories U10-U19. However, the most notable influence was proven in the category U10-U11. The influence of RAE was observed in the players of FIFA U17 World Cup Emirates 2013 and it was found out that the influence of RAE was statistically important in qualifying tournament, but not in final round (Andrade-Souza et al., 2015).

It cannot be stated that if the number of elite players born in the first half of the year $\left(Q_{1}\right.$, $\left.\mathrm{Q}_{2}\right)$ surpasses the number of players born in the second half of the year $\left(\mathrm{Q}_{3}, \mathrm{Q}_{4}\right)$, they are more talented.

On the base of literary research containing more than 140 publications we found out that in sport shooting there has not been any study of RAE. As the most similar sport in which RAE was tested was chosen tennis, based on its sensorimotor features. In this sport, the influence of RAE in multinational junior tournament in the years 2012-2016 (Bozděch et al., 2017) was confirmed. Different influence based on sex was confirmed by Filipcic (2001), when he found out that the influence of RAE was confirmed among boys in categories U12, U14, U16 (not 
confirmed in category U18), but among girls it was confirmed in categories U12 and U14 (not confirmed in categories U16 and U18). What is interesting about the conclusion of the study conducted by Loffing, Schorer, and Cobleye (2010) is that they found out that the influence of RAE is statistically important among the players of ITP with the dominant right hand, but not among the players with the dominant left hand. Agricola et al. (2015) researched the influence of RAE on sport successfulness, but no connections between the sport successfulness and the date of birth were found. Thanks to different conditions and systems for the identification of athlete talents, there may be observed various conclusions connected to the influence of RAE in various categories. For example, Pacharoni, Aoki, Costa, Moreira, and Massa (2014) found out that the influence of RAE is significant in the junior level, but not in the professional level of Brazilian players ITP. Ulbricht, Fernandez-Fernandez, Mendez-Villanueva, and Ferrauti (2015) reached the opposite conclusion, when they found out that in Germany the influence of RAE grew with each following level (age and performance), what may be an effect of talent programs which exist in Germany from the category U12.

\section{SHOOTING SPORTS IN GENERAL}

According to Paulík (2006), the right choice of athletic talents is one of the main and key questions of today's sport. By the right choice, it is possible to shorten significantly the development of athlete in given sport or sport discipline. At the same time there is a need to calculate with the fact, that every population provides a complete talent spectrum for every sport. National sport federations and clubs then create the criteria for selection of these talents.

Málek (1989) describes the fact that shotgun shooting, which got into the general public opinion in $18^{\text {th }}$ century as a popular activity among higher levels of society. It is a part of modern Olympic Games since its establishment in 1900, even though at the time as shooting and not as shotgun shooting. Since that time the shotgun shooting has developed. Not only as a sport in general, but also its disciplines as well (skeet, trap, doubletrap). Nowadays it is not only a sport for rich people. Sport clubs are trying to provide suitable conditions for everyone, who wants to engage in this sport. If everyone had an opportunity to try shotgun shooting, there would be no talent wasted.

According to Bedřich (2006), sport training is long-term matter and this phenomenon needs to be considered during the choice of athletic talents. Achieving of maximal sport performance has always been preceded by a long-term preparation for pressure, not only physical but also mental. In every case should be regarded with the specifics and rules of the particular sport discipline together with basic principles of sport training.

Shotgun shooting is a sport which considerably lacks systematic concept in the choice of talents and given sport area is overall not very explored. Current practice of the choice of starting players depends only on the trainer, who asses the talent. Trainer takes into consideration the somatotype of athletes, physical condition and mental condition. Based on the fact that given sport is performed with a gun, in the case of shotgun shooting sport gun is certain mental maturity and physical condition of a starting athlete required. Because of this reason are only very rarely accepted athletes younger than 12 . As the mental and physical requirements are so high for starting athletes, the choice of talents is considerably restricted. This is the reason why it is necessary to pay attention to every factor which may influence the choice of talent, as in our case the influence of Relative Age Effect. 


\section{METHODOLOGY}

The compilation of data was obtained with the consent of leaders of two top Czech sport shooting clubs. The respondents were chosen by the athletes of these clubs, who form together the Czech National Team in the year 2016/2017 $(n=35)$. Median of birth in Czech National Team is 1994. Particularly, it is a club Kometa Brno ( $n=26,11$ men, 6 women) which fall within the department of Ministry of the interior based in Brno and club Dukla Hradec Králové ( $n=9,7$ men, 2 women) which fall under the army resort, with place of operation in Hradec Králové.

The whole group is formed by several sub-categories. These sub-categories are formed of disciplines of shotgun shooting, age and sex. The disciplines are skeet and trap. Younger shooters are in junior categories (category up to 20 years included) and senior category, or rather men and women (category from 21 years). Senior category of men is divided into representative categories A, B, C; and these sub-categories have special criteria of division. For the purposes of the study is used the whole category, senior men category. On the contrary, for the purposes of the study was created the category which divides group into athletes who participated in prominent multinational competitions, such as European Championship, World Championship, World Cup and Olympic Games (ME, MS, SP, OH) and into shooters, who have not taken part such competition.

Researched data were statistically analyzed by the mean of chi-squared test $\left(\chi^{2}\right)$ in verification of Goodness-of-fit and Kolmogorov-Smirnov test (KS). We observed distribution (date of birth in $\mathrm{Q}_{\mathrm{i}}$ ) and compared it with the expected distribution (number of children born in Czech Republic in 1994 in $\mathrm{Q}_{\mathrm{i}}$ ), which we obtained from the publicly available database (data.un.org), it is as follows: $\mathrm{Q}_{1}=26.35 \% ; \mathrm{Q}_{2}=27.97 \% ; \mathrm{Q}_{3}=24.32 \% ; \mathrm{Q}_{4}=21.37 \%$. For more accurate assessment of the influence of RAE was apart from $\chi^{2}$ test calculated also Cramer's V (V), mainly for the purpose of assessing the power of association with expected and observed distribution. For our degree of freedom $(\mathrm{df}=3)$ has according to Cohan $(1988)$ the following interpretation: small $(\mathrm{V}<0.17)$, medium $(\mathrm{V}<0.29)$, or large effect $(\mathrm{V} \geq 0.29)$.

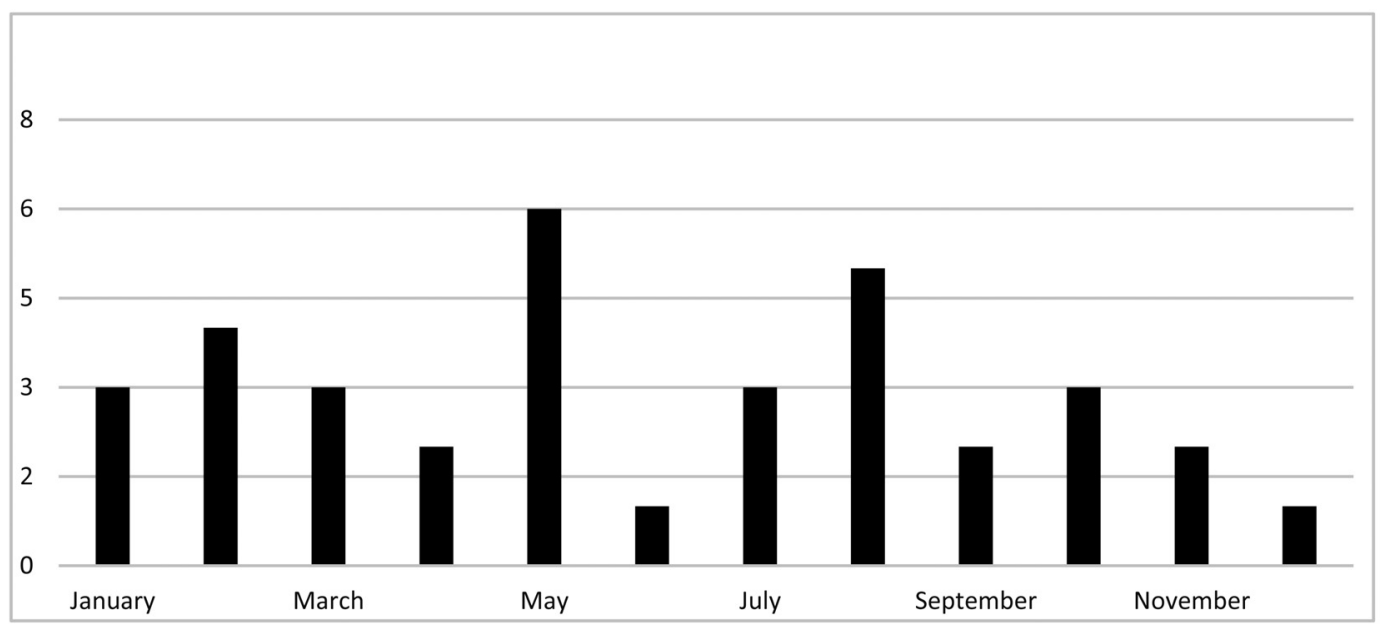

Fig. 1: Distribution of Date of Birth of Dukla Hradec Hrálove and Kometa Brno Divided into Months.

In the figure 1, you can see the division of the whole observed group $(\mathrm{n}=35)$ by months. 


\section{AIM OF STUDY}

Research questions for the study are the following:

Is the influence of Relative Age Effect provable in the whole observed group?

What is the difference in the influence of Relative Age Effect on the categories of junior and senior?

What is the influence of Relative Age Effect on shooters who represented the Czech Republic in European Championship, World Championship, World Cup and Olympic Games?

\section{RESULTS}

\section{Influence of RAE on the Whole Observed Group}

Methodology concerning RAE issue uses the date of birth division based on quarters $\left(\mathrm{Q}_{\mathrm{i}}\right)$, which is displayed in the following table 1 . This table contains the division of the whole group $(n=35)$ in individual quarters $\left(\mathrm{Q}_{\mathrm{i}}\right)$. The table consists of chi-squared test and Cramer's V.

Tab. 1: Influence of RAE on Players of Club Dukla and Kometa Brno.

\begin{tabular}{|c|c|c|c|c|c|c|c|c|c|}
\hline & $Q_{1}$ & $\mathbf{Q}_{2}$ & $\mathbf{Q}_{3}$ & $\mathbf{Q}_{4}$ & $\mathrm{n}$ & $\chi^{2}$ & p & V & ES \\
\hline $\begin{array}{l}\text { Absolute } \\
\text { Relative }\end{array}$ & $\begin{array}{c}10 \\
28.57 \%\end{array}$ & $\begin{array}{c}9 \\
25.71 \%\end{array}$ & $\begin{array}{c}10 \\
28.57 \%\end{array}$ & $\begin{array}{c}6 \\
17.14 \%\end{array}$ & $\begin{array}{c}35 \\
100 \%\end{array}$ & 0.68 & 0.88 & 0.08 & Small \\
\hline Relative & \multicolumn{2}{|c|}{$\mathrm{S}_{1}=54.28 \%$} & \multicolumn{2}{|c|}{$S_{2}=45.71 \%$} & $100 \%$ & - & - & - & - \\
\hline
\end{tabular}

Note. $Q_{i}=$ quarters; $S_{i}=$ semester $; \chi^{2}=$ chi-squared test; $p=p$-value; $V=$ Cramer's $V ; E S=$ effect size.

It is noticeable that the lowest value in the tracked group in the table 1 is in the $\mathrm{Q}_{4}$, however, based on chi-squared test $\left(\chi^{2}\right)$, its influence is statistically not important $(p=0.88)$. The associated influence in between the selected variables were Cramer's V negligible $(\mathrm{V}=0.08)$.

\section{Influence of RAE on different age categories}

In the following table 2, the influence of RAE on the categories of junior and senior may be observed. Due to not fulfilling the conditions necessary for chi-square test the Kolmogorov-Smirnov test was used instead of Goodness-of-fit test.

Tab. 2: Effect of RAE on the Categories of Junior and Senior.

\begin{tabular}{|l|l|c|c|c|c|c|c|c|}
\hline Category & & $\mathbf{Q}_{\mathbf{1}}$ & $\mathbf{Q}_{\mathbf{2}}$ & $\mathbf{Q}_{\mathbf{3}}$ & $\mathbf{Q}_{\mathbf{4}}$ & $\mathbf{n}$ & $\mathbf{D}_{\max }$ & $\mathbf{C V}$ \\
\hline Junior & Absolute & 3 & 6 & 6 & 0 & 15 & 0.212 & 0.338 \\
& Relative & $20.00 \%$ & $40.00 \%$ & $40.00 \%$ & $0.00 \%$ & $100 \%$ & & \\
\hline Senior & Absolute & 7 & 3 & 4 & 6 & 20 & 0.088 & 0.294 \\
& Relative & $35.00 \%$ & $15.00 \%$ & $20.00 \%$ & $30.00 \%$ & $100 \%$ & & \\
\hline
\end{tabular}

Note. $C V=$ critical values $(0,05)$ for $D_{\max }$.

In the table 2 there can be observed that the lowest value in junior category is in $\mathrm{Q}_{4}\left(\mathrm{Q}_{4}=0\right.$; i.e. $0.00 \%)$ and vice versa, the highest value in senior category is in $Q_{1}\left(Q_{1}=7\right.$; i.e. $\left.35.00 \%\right)$. Nevertheless, with the Kolmogorov-Smirnov test there was not indicated the influence of date of 
birth neither in junior category $\left(D_{\max }=0.212<C V=0.338\right)$ nor senior category $\left(D_{\max }=0.088\right.$ $<\mathrm{CV}=0.294)$. According to the result of Kolmogorov-Smirnov test there can be further stated, that the influence of RAE (although insignificant) is stronger in junior category $\left(D_{\max }=0.212\right.$ ) than in senior category $\left(D_{\max }=0.088\right)$.

The last table of this study contains only shooters $(n=28)$, who participated in competitions European Championship, World Championship, World Cup and Olympic Games (later ME, MS, SP, OH).

Tab. 3: Influence of RAE in the Category of shooters, who Participated in Top Competitions (ME, MS, $\mathrm{SP}, \mathrm{OH})$.

\begin{tabular}{|c|c|c|c|c|c|c|c|c|c|}
\hline & $Q_{1}$ & $\mathbf{Q}_{2}$ & $\mathbf{Q}_{3}$ & $\mathbf{Q}_{4}$ & $n$ & $\chi^{2}$ & $p$ & V & ES \\
\hline $\begin{array}{l}\text { Absolute } \\
\text { Relative }\left(Q_{i}\right)\end{array}$ & $\begin{array}{c}9 \\
32.14 \%\end{array}$ & $\begin{array}{c}6 \\
21.43 \%\end{array}$ & $\begin{array}{c}7 \\
25.00 \%\end{array}$ & $\begin{array}{c}6 \\
21.43 \% \\
\end{array}$ & $\begin{array}{c}28 \\
100 \% \\
\end{array}$ & 0.79 & 0.85 & 0.10 & Small \\
\hline Relative $\left(S_{i}\right)$ & \multicolumn{2}{|c|}{$S_{1}=53.57 \%$} & \multicolumn{2}{|c|}{$S_{2}=46.43 \%$} & $100 \%$ & - & - & & - \\
\hline
\end{tabular}

Table 3 shows certain influence of date of birth in number of shooters in certain quarters $\left(Q_{i}\right)$ as well. The highest value can be observed in $\mathrm{Q}_{1}\left(\mathrm{Q}_{1}=9\right.$; i.e. 32.14\%). According to chi-squared test these values are statistically negligible $(p=0.85)$ and according to Cramer's V the association between variables is negligible $(\mathrm{V}=0.10)$.

\section{DISCUSSION}

The results obtained show, that the influence of RAE in shotgun shooting is statistically negligible. Nevertheless, there is noticeable difference in between junior and senior categories. The force of the influence of RAE is higher on junior level than on senior level.

This fact is partially in accordance with Coutts, Kempton and Vaeyens (2014), who studied the influence of RAE in Australian draft in the highest league AFL in years 2001-2012. It showed significant influence of RAE among players below and above 20 years. Just as in our study was the influence of RAE in younger category more powerful $\left(<20\right.$ years $\chi^{2}=28.7 ; \geq 20$ years $\left.\chi^{2}=8.0\right)$.

This fact partially corresponds with study by Coutts, Kempton, and Vaeyens (2014), who researched the influence of RAE in Australian.

In contrary, Ubricht et al. (2015) found out that the influence of RAE in Germany is more significant in every next performance group, players (U1-U18) who were born in $\mathrm{Q}_{1}$ had the following representation in various performance levels: registered players $24.3 \%$, players in ladder ITP $29.6 \%$, regional selection $38,1 \%$, national selection $42.1 \%$ (expected number $24.7 \%$ ). In other words, the influence is exactly the opposite to our findings. One of the possible explanations are countless centers for talented youth in Germany, into which there are chosen the players in young age.

With a similar size of study group worked Camacho-Cardenosa et al. (2018), who researched the influence of RAE in handball (23 males and 24 females, $13.26 \pm 0.44$ years). Their values of women's group $\left(\chi^{2}=0.89 ; p=0.35\right)$ were comparable with our calculated value of $\chi^{2}$ in the whole group $\left(\chi^{2}=0.68 ; p=0.88\right)$ and among the participants of top-level competitions $\left(\chi^{2}=0.79\right.$; $p=0.85)$. In the men's group the authors found even lesser influence of RAE than in women's group $\left(\chi^{2}=0.064 ; p=0.8\right)$. 


\section{CONCLUSION}

In the whole group ( $n=35)$ was not observed by the mean of chi-squared test any significant difference between expected and observed value $\left(\chi^{2}=0.68 ; p=0.88\right)$, therefore there was no influence of RAE. Next, the RAE influence in junior category $(n=15)$ and senior category $(n=20)$. Based on Kolmogorov-Smirnov test (KS), the influence of RAE is not significant neither in junior category $\left(D_{\max }=0.212<\mathrm{CV}=0.338\right)$ nor senior category. $\left(\mathrm{D}_{\max }=0.088<\mathrm{CV}=0.294\right)$. Even though none of categories (junior, senior) according to KS test showed expected distribution of the date of birth, we can state that the junior category is more likely to be influenced by the RAE than the senior category.

Then, we researched the influence of RAE among sport shooters, who represented the Czech Republic on a multinational level (ME, MS, SP, OH) and we found out that according to chisquared test the influence of RAE is not significant $\left(\chi^{2}=0.79 ; p=0.85\right)$ the association between the variables is none $(\mathrm{df}=3 ; \mathrm{V}=0.1)$.

Even though from an objective point of view the influence of RAE is evident, none of our tests found out statistically important influence of the date of birth in sport shooters in any category. These results are not surprising, as one of the criteria for the influence of RAE is the competition (which is numerous enough) in the category. Moreover, we consider the advantages resulting from the date of birth of relatively older athletes who were born in the first half of the year, such as height and weight, are not so fundamental for shotgun shooters. Even from the recruitment of athletes the importance is put on the physical construction and physical readiness of the body to absorb back pressure. Despite the fact that this work consists of only a small observed group from which the general conclusions are difficult to obtain, it consists of approximately $30 \%$ of all registered Czech shooting athletes and $90 \%$ of the Czech National Team. Based on not proving the influence of date of birth in all observed criteria of our group we assume that the current method of choice of shooting athletes does not need to be adjusted in order to eliminate the influence of RAE.

\section{References}

Agricola, A., Psotta, R., \& Abdollahipour, R. (2015). Relativný efekt veku na sútažnú úspešnost' v tenise u dětí staršieho školského veku. Telesna Kultura, 38(1), 30-43.

Andrede-Souza, V., Moniz, F., \& Teoldo, I. (2015). Relative age effect in FIFA U17 Emirates 2013 World Cup: analysis of players who effectively participated in the matches. Motriz: Revista de Educação Física, 21 (4), 403-406. doi:10.1590/ S1980-65742015000400009.

Barnsley, R., Thompson, A., \& Barnsley, P. (1985). Hockey success and birthdate: the relative age effect. Cahper Journal, 51(8), 23-28.

Coutts, A., Kempton, T. \& Vaeyens, R. (2014) Relative age effects in Australian Football League National Draftees, Journal of Sports Sciences, 32(7), 623-628, doi: 10.1080/02640414.2013.847277.

Bedřich, V. (2006). Fotbal rituální hra moderní doby. Brno: MU. $195 \mathrm{~s}$.

Bozděch, M., Nykodým, J., Agricola, A., \& Zháněl, J. (2017). The relative age effect in the world junior tennis finals 2012-2016 (male). In M. Zvonař (Ed.), "11th International Conference on Kinanthropology. Sport and quality of life." (p. 45). [Book of abstrats]. Brno: Masarykova univerzita.

Cohen, J. (1988). Statistical power analysis for the behavioral sciences (2nd ed.). Hillsdale, NJ: Erlbaum.

Deprez, D., Vaeyens, R., Coutts, A. J., Lenoir, M., \& Philippaerts, R. (2012). Relative age effect and Yo-Yo IR1 in youth soccer. International Journal of Sports Medicine, 33(12), 987-993. doi:10.1055/s-0032-1311654.

Filipcic, A. (2001). Birth date and success in tennis, Coaching \& sport science review, 23, 9-11.

Green, D. R., \& Simmons, S. V. (1962). Chronological age and school entrance. The Elementary School Journal, 63(1), 41-47.

Loffing, F., Schorer, J., \& Cobley, S. P. (2010). Relative Age Effects are a developmental problem in tennis: but not necessarily when you're left-handed!. High Ability Studies, 21(1), 19-25.

Málek V. (1989). Sportovní střelba. Praha: ÚV Svazarmu. 139 s. ISBN 80-7062-109-5. 
Pacharoni, R., Aoki, M. S., Costa, E. C., Moreira, A., \& Massa, M. (2014). Efeito da idade relativa no Tênis. The relative age effect in Tennis. Revista Brasileira De Ciência E Movimento, 22(3), 111-117.

Paulík, K. (2006). Psychologie sportu. Ostrava: FF. $154 \mathrm{~s}$.

Ulbricht, A., Fernandez-Fernandez, J., Mendez-Villanueva, A., \& Ferrauti, A. (2015). The Relative Age Effect and Physical Fitness Characteristics in German Male Tennis Players.Journal of Sports Science \& Medicine, 14(3), 634-642. 